This document is the accepted manuscript version of the following article:

Spiegelberger, T., Deléglise, C., DeDanieli, S., \& Bernard-Brunet, C. (2010).

Resilience of acid subalpine grassland to short-term liming and fertilisation. Agriculture, Ecosystems and Environment, $137(1-2), 158-162$.

https://doi .org/10.1016/j . agee.2010.01.017

\title{
Resilience of acid subalpine grassland to short-term liming and fertilisation
}

Thomas Spiegelberger ${ }^{1,2,3}$, Claire Deléglise ${ }^{1}$, Sébastien DeDanieli ${ }^{1}$, Claude Bernard-Brunet ${ }^{1}$

${ }^{1}$ Cemagref, Research Unit Mountain Ecosystems, 2 rue de la Papeterie, BP 76, F-38402

Saint-Martin-d'Hères, France

${ }^{2}$ Ecole Polytechnique Fédérale de Lausanne (EPFL), Laboratory of Ecological Systems

(ECOS) - Swiss Federal Institute for Forest, Snow and Landscape Research (WSL), and

Restoration Ecology Research Group, Site Lausanne, station 2, CH-1015 Lausanne,

Switzerland

${ }^{3}$ Corresponding author: tel: 00334767628 19, fax: 00334765138 03, email:

thomas.spiegelberger@cemagref.fr

Words in abstract: 273

Pages: 18

Number of Tables: 3

Number of Figures: 1

Number of Annexes: 1 


\begin{abstract}
A fertilisation experiment was started in the French Alps on an acid grassland at $2000 \mathrm{~m}$ in 1989 where lime as calcium carbonate ("liming”) and Thomas Slag enriched by potassium chloride ("fertilisation") was added in a random block design until 1992. Since then, no further amendments were applied.
\end{abstract}

Fifteen years after the last application, we revisited the experiment and observed that soil $\mathrm{pH}$ was still significantly higher on limed plots, while nitrogen $(\mathrm{N})$ concentrations were lower. On fertilised plots, soil carbon (C) and $\mathrm{N}$ concentrations were lower compared to unfertilised plots. However, litter quality ( $\mathrm{C}$ and $\mathrm{N}$ concentrations, near infrared spectroscopy [NIRS] data) was similar for both treatments. Vegetation composition, but not species richness, nor Shannon-Wiener or evenness differed between limed and unlimed plots, and fertilised and unfertilised plots. Liming explained about $18 \%$ and fertilisation about $6 \%$ of the variability of the vegetation composition. These changes in the vegetation composition are probably due to lower abundances of former dominant grass species and to an increase in generalist grasses. However, these changes did not influence the total aboveground productivity, which was similar for all treatments. Tissue $\mathrm{N}$ and $\mathrm{C}$ concentrations and NIRS data indicated a changed chemical composition of the biomass which persisted during time.

\footnotetext{
We conclude that the three years of fertilisation and liming did substantially influence the vegetation composition at our site and lead to an increase in the agricultural value of the grassland. These changes are long-lasting as they changed key features of the functioning in the soil of grasslands ecosystems. From an ecological point of view, specialised vegetation was replaced by generalist species leading to a trivialisation of the vegetation.
} 
Keywords: long-term fertilisation experiment; ecosystem resilience; soil-plant interactions;

1 


\section{Introduction}

Species rich acid grasslands in mountain areas dominated by nard grass (Nardus stricta L.), classified as NATURA 2000 habitat type 6230, are widely distributed throughout Europe and harbour some valuable species. Nevertheless, the area occupied has declined in Europe in the last decades through either intensification of agricultural practices or land abandonment and too low intensive use. Species rich acid grasslands are prairies of low to intermediate productivity, which are in general used for extensive cattle grazing and their floristic composition has coevolved with these practises. In order to sustain a higher cattle stocking rate, different attempts have been made to increase their productivity since the early 1930s, many of which led to a decrease of the floristic diversity of these previously species rich acid grasslands (Schellberg et al., 1999).

Long-term studies have shown that plant species richness, biomass and $\mathrm{pH}$ are related and that fertilisation has a negative effect upon species richness through increases in biomass (Crawley et al., 2005; Silvertown et al., 2006). However, once the fertilisation treatments are stopped, productivity of former fertilised grasslands decreases and vegetation composition and species richness approach pre-treatment levels. This has been shown for nitrogen fertilisation, while phosphorus fertilisation seems to have a more persistent effect (Smits et al., 2008).

Soil amendments, in particular fertiliser or lime, increase the soil nutrient availability and change the $\mathrm{pH}$, a key determinant of microbial community composition (Bååth and Anderson, 2003). Changes in the belowground ecosystem induced by soil amendments are likely to 
favour competitive plant species that have high rates of nutrient acquisition, high relative growth rates, and high tissue nutrient concentrations. Leaf litter of these plants is often favourable to decomposers and breaks down more rapidly than that of plant species adapted to low-nutrient conditions (Cornelissen et al., 1999). This feedback between aboveground and belowground food communities may generate relatively stable associations and thereby decreases the ecosystem's resilience or even drive the ecosystem to an alternative state (Wardle, 2002).

Changing the soil nutrient availability through soil amendments raises questions about ecosystem resilience which is defined as the time an ecosystems needs to recover from a perturbation or to attain another stable state (May, 1973). Resilience is affected by a number of ecosystem properties including nutrient cycling and it is supposed that the resilience of an ecosystem depends on its nutrient turnover rate (DeAngelis et al., 1989). Consequently, resilience to perturbations and in particular to changes in key ecosystem properties ( $\mathrm{pH}$ or $\mathrm{P}$ ) of grassland ecosystems under harsh environmental conditions may be particularly low (Spiegelberger et al., 2006; Hejcman et al., 2007) and may even be irreversible (Semelová et al., 2008).

Here an experiment is presented in which the resilience of a subalpine grassland and the effects of liming and fertilisation 15 year after cessation of treatments were investigated. On a grassland dominated by nard grass in the French Alps, lime and fertiliser were applied from 1989 to 1992 . Within a few years vegetation composition changed significantly (Brau-Nogue, 1996). The main hypothesis under study is that despite high leaching due to precipitation, soil but also plant chemical properties continue to be influenced by soil amendments, that vegetation composition still differs between treated and control plots and that in consequence, 
15 years are not enough to allow returning of key ecosystem components towards the initial state.

\section{Materials and methods}

\subsection{Study site and experimental design}

The experiment was set up in 1989 in a mountain pasture in the Northern French Alps $\left(45^{\circ} 46^{\prime} \mathrm{N} ; 6^{\circ} 35^{\prime} \mathrm{E}\right)$ on a subalpine grassland. It is situated on a south facing slope of $40^{\circ}$ at an altitude of $2000 \mathrm{~m}$ asl. The 10 -year mean annual temperature is ca. $5^{\circ} \mathrm{C}$ and mean annual precipitation is about $1600 \mathrm{~mm}$, with about $500 \mathrm{~mm}$ falling during the summer months (http://climatheque.meteo.fr). At the begining of the study, the soil (calcschist) was of low fertility (total N: 5.4\%; total C: 34\%; $\mathrm{CaO}: 0.07 \% ; \mathrm{P} 2 \mathrm{O} 5: 0.009 \% ; \mathrm{K} 2 \mathrm{O}: 0.09 \% ; \mathrm{MgO}$ : $0.03 \%$ ) and had a pH of 5.0 (Brau-Nogue, 1996). At this time, the site was dominated by Deschampsia flexuosa L. and N. stricta (cf. annex 1). Further species with an average cover of $5 \%$ to $8 \%$ were Potentilla erecta L., Leontodon sp. L., Geum montanum L., and Gentiana kochiana L. (Brau-Nogue, 1996). The site had been traditionally used as a dairy pasture without additional fertilisation for many centuries but management has become very extensive since the 1950s with low summer grazing pressure and no fertilisation. Since the beginning of the study, the site was grazed mainly by heifers with about 0.2 livestock units per ha.

Twelve plots ( 2 x $10 \mathrm{~m}$ each, the long side parallel to the main altitudinal gradient) were arranged in three randomized blocks. The blocks were each separated by a $1 \mathrm{x} 10 \mathrm{~m}$ path and arranged in a single row. Two fertiliser treatments, liming as calcium carbonate (from hereon “liming” or Ca) and Thomas Slag (a by-product from steel manufacture process, rich in lime 
and phosphoric acid; "fertiliser" or PK), were applied in a full-factorial design once a year from 1989 to 1991 , resulting in four treatments labelled $\mathrm{Ca}^{+} / \mathrm{PK}^{+}, \mathrm{Ca}^{-} / \mathrm{PK}^{+}, \mathrm{Ca}^{+} / \mathrm{PK}^{-}, \mathrm{Ca}^{-} / \mathrm{PK}^{-}$ (corresponding to the control). The limed plots received a total calcium carbonate amount of $5400 \mathrm{~kg} \mathrm{ha}^{-1}$ (equivalent of $2143 \mathrm{~kg} \mathrm{ha}^{-1} \mathrm{Ca}$ ), the fertilised plots a total amount of $1500 \mathrm{~kg} \mathrm{ha}^{-}$

${ }^{1}$ Thomas slag (P: $79 \mathrm{~kg} \mathrm{ha}^{-1}$; Ca: $\left.407 \mathrm{~kg} \mathrm{ha}^{-1}\right)$ and $750 \mathrm{~kg} \mathrm{ha}^{-1} \mathrm{KCl}\left(\mathrm{K}: 187 \mathrm{~kg} \mathrm{ha}^{-1}\right)$.

\subsection{Sampling and analysis}

Three soil cores ( $3 \mathrm{~cm}$ diameter, $5 \mathrm{~cm}$ depth) were collected in each plot in August 2007. Samples were air-dried before litter, defined as degrading plant material lying at the top of the soil, was visually separated from soil. The remaining soil was then passed through a 2-mm sieve. Soil $\mathrm{pH}$ was determined with an electrode in a 1:5 mixture with deionised water in each sample.

Vegetation composition was recorded in mid-June 2007 in three randomly selected $1-\mathrm{m}^{2}$ subplots in each plot. The vegetation cover (as percentage of ground cover) for all species of vascular plants was estimated to the nearest $1 \%$ as agreed by two observers. Plant biomass was sampled in 2007 at the peak standing biomass from a $1 \mathrm{~m}^{2}$ stripe $(0.1 \times 10 \mathrm{~m})$ located in the middle of each plot. Biomass was dried at $60^{\circ} \mathrm{C}$ during $48 \mathrm{~h}$ and weighed. Afterward, three subsamples were taken in each biomass sample and further used for NIRS analysis. The carbon $(\mathrm{C})$ and nitrogen $(\mathrm{N})$ content of soil, litter and biomass samples was determined in three samples per plot using a Thermo ANTARIS II FT-NIR Analyzer (Thermo Fisher Scientific Inc., Milano, Italy) according to the manufacturer's instructions.

Soil, litter and biomass samples were ground to $0.25 \mathrm{~mm}$ to obtain homogeneous powders for NIRS analysis, the later two also cut in small pieces beforehand. The ground material was dried at $40^{\circ} \mathrm{C}$ and stored in a chamber with silica gel prior analysis. For all samples material 
was packed into a sample cell with a quartz window and the spectrum recorded by a

Fourier49 transform NIR spectrophotometer Antaris II (Thermo Fisher Scientific Inc.,

Milano, Italy). Each spectrum was produced of 32 averaged scans of the sample.

Measurements were made over a range of $1000 \mathrm{~nm}$ to $2500 \mathrm{~nm}$ to produce a spectrum with 6224 relectance points. Reflectance $(\mathrm{R})$ of monochromatic light was converted to absorbance (A) using the equation $\mathrm{A}=\log (1 / \mathrm{R})$.

\subsection{Data analysis}

Mean species diversity per plot was calculated using the Shannon diversity index: $\mathrm{H}^{\prime}=-\Sigma p_{i}$ $\left(\log \left(p_{i}+1\right)\right)$ where $p_{i}$ is the vegetation cover per $1-\mathrm{m}^{2}$ subplot for each species i per $1-\mathrm{m}^{2}$ subplot. Evenness was computed as $\mathrm{J}=\mathrm{H}^{\prime} / \log (\mathrm{S})$ where $\mathrm{S}$ is the species richness. Species richness $(\mathrm{S})$ is the cumulative number of species encountered across the three subplots. The forage quality was characterized by the pastoral value (VP) calculated as : VP=0.2 $\Sigma\left(\mathrm{p}_{\mathrm{i}} \mathrm{x} \mathrm{Is}_{\mathrm{i}}\right)$ where $p_{i}$ is the vegetation cover per $1-\mathrm{m}^{2}$ subplot accounted for by species $\mathrm{i}$ in vegetation relevés, and where $\mathrm{Is}_{\mathrm{i}}$ is the specific index of forage quality of species $\mathrm{i}$ (Daget and Poissonet, 1972). Landolt mean indicator indices for nutrients ( $\mathrm{N}$-value 1-5: very nutrient poor to very nutrient rich) and for soil reaction or $\mathrm{pH}$ (R-value 1-5: very acid to very basic) were calculated from ecological indicator values for individual plants produced by Landolt (1977). Scores were weighted to take account of the relative contribution of each species to the total vegetation cover.

Univariate data were analyzed by analysis of variance (ANOVA) to test for the effect of liming, fertilisation and their interaction. Analyses were performed for the species richness and diversity, individual plant species, forage quality, biomass, $\mathrm{N}$ - and $\mathrm{C}$-content of soil, litter and vegetation, $\mathrm{pH}$ and Landolt mean indicator indices using the factor block, liming and fertilisation and the interaction between liming and fertilisation. 
Multivariate analysis of the vegetation composition and of the standardised and centred NIRS spectra were carried out using redundancy analysis (RDA), a constrained form of principal component analysis (Leps and Smilauer, 2003). Vegetation data were log-transformed prior to analysis and, to eliminate interferences of scatter, the spectral data were transformed with first and second derivative processing. RDA was carried out with the derivatives for the wavelength range from 1650 to $1750 \mathrm{~nm}$. Variables used in the analysis were block, fertilisation and liming, and were tested using a Monte Carlo permutation test (999 permutations). ANOVAs were carried out using R statistical language (version 2.4.1) and corresponding packages. RDA was calculated by Canoco (version 4.5).

\section{Results}

\subsection{Soil and litter}

Soil $\mathrm{pH}$ was still significantly influenced by liming and the interaction between $\mathrm{Ca} \mathrm{x} \mathrm{PK}$ (Table 1). The interaction showed that the increase in $\mathrm{pH}$ from unlimed to limed plots was significantly higher when plots were not fertilised (Fig. 1). However, soil $\mathrm{pH}$ was higher on limed compared to unlimed plots $(5.9 \pm 0.05$ vs. $5.3 \pm 0.05 \mathrm{pH}$ units $)$. Soil $\mathrm{N}$ concentrations were lower in limed compared to unlimed plots $(0.8 \pm 0.05 \%$ vs. $1.0 \pm 0.05 \%)$ and in fertilised compared to unfertilised plots $(0.8 \pm 0.06 \%$ vs. $1.0 \pm 0.04 \%)$. Soil C concentration was not influenced by liming $(11.0 \pm 0.91 \%$ vs. $12.7 \pm 0.83 \%)$, but fertilised had a lower C concentration than unfertilised plots $(10.7 \pm 0.92 \%$ vs. $12.9 \pm 0.78 \%)$. Soil C:N ratio was not influenced by the treatments $(P>0.05)$. Soil quality assessed through RDA of the NIRS spectra did not reveal changes due to treatments $(P>0.05)$ and about $80 \%$ of the variability of the data remained unexplained. 
Liming and fertilisation both increased Landolt $\mathrm{N}$-values $(\mathrm{Ca}:+0.21 ; \mathrm{PK}:+0.22$, Table 1$)$. Similarly to soil $\mathrm{pH}$, liming increased the Landolt R-value $(+0.29)$, which was also higher after fertilisation $(+0.24$, Table 1$)$.

Neither $\mathrm{N}$ nor $\mathrm{C}$ content of the litter was significantly affected by liming or fertilisation $(\mathrm{F}<$ $2.1 ; P>0.2)$. Correspondingly, RDA on litter chemical composition assessed trough NIRS did not reveal any treatment effect $(P>0.3)$.

\subsection{Vegetation}

There was no treatment effect on species richness per $1 \mathrm{~m}^{2}$ (overall mean: $31.6 \pm 0.89$; range: 23 to 35 plant species), neither on Shannon diversity index (overall mean: $2.93 \pm 0.023$ ), nor on evenness index (overall mean: $0.95 \pm 0.002$; for both $F<2.1, P>0.2$ ). However, 15 years after the last application, liming and fertilisation still had a significant effect on vegetation composition. Liming accounted for $18.9 \%$ of the variability in vegetation composition $(F=$ 9.2; $P<0.001)$, fertilisation for $6.4 \%(F=3.1 ; P<0.001)$, their interaction for $2.0 \%(P>$ 0.1 ), and blocks for $11.6 \%$ (not tested).

Plots that were neither limed nor fertilised were dominated by N. stricta, F. rubra and D. flexuosa while plots which received lime were characterized by a low proportion of the initially dominant acidophilous grasses $N$. stricta and $D$. flexuosa and a higher proportion of the generalist grasses F. rubra and Phleum alpinum L. (Table 2). The proportion of forbs or legumes typical of nutrient-poor grasslands such as T. alpinum, G. kochiana, or Arnica montana L. was lower in limed plots. Plots that were only fertilised presented intermediate proportions of $N$. stricta and F. rubra. In contrast to limed plots, T. alpinum was not reduced on plots only fertilised. Plots that were both limed and fertilised were characterized by a very high proportion of legumes that were hardly present on unlimed and unfertilised plots 
(Trifolium badium Schreb., Trifolium repens L., Trifolium pratense L., Table 2) and by the absence of T. alpinum.

Fifteen years after cessation of application, total above-ground biomass was similar for all treatments (overall mean: $2.17 \mathrm{t} \mathrm{ha}^{-1} ; F<0.4, P>0.5$ ). However, plant tissue $\mathrm{N}$ and $\mathrm{C}$ concentrations were still affected by liming and fertilisation. Herbage $\mathrm{N}$ concentration was significantly higher in fertilised plots than in unfertilised plots $(2.2 \pm 0.06 \%$ vs. $1.9 \pm 0.04 \%)$ and herbage $\mathrm{C}$ concentration was significantly lower in limed plots than in unlimed plots $(42.1 \pm 0.44 \%$ vs. $44.1 \pm 0.25 \%$, Table 3$)$. Plant tissue C:N ratio was significantly lower on fertilised than in unfertilised plots $(20.0 \pm 0.55$ vs. $23.4 \pm 0.49)$.

The RDA ordination conducted on NIRS spectra of plant tissue composition showed a tendency for liming and was significantly affected by fertilisation $(\mathrm{Ca}: F=2.6, P=0.066$; PK: $F=6.5 ; P=0.002)$. Consequently, liming accounted for $6.0 \%$ of the spectra variability, fertilisation for $14.7 \%$, and blocks for $8.5 \%$.

Liming and fertilisation still had a strong effect on the pastoral value after 15 years of cessation of the amendments. The pastoral value was $42 \%$ higher on limed plots than on unlimed plots $(30 \pm 1.9$ vs. $21 \pm 1.5 ; \mathrm{F}=34.3 ; \mathrm{p}=0.001)$ probably due to a reduction of the cover of N.stricta $\left(\mathrm{I}_{\mathrm{s}}=0\right)$ and D. flexuosa $\left(\mathrm{I}_{\mathrm{s}}=1\right)$, both acidophilous grass species with low nutritive quality. On fertilised plots, pastoral value was $43 \%$ higher than on non-fertilised plots $(30 \pm 2.0$ vs. $21 \pm 1.4 ; F=35.7 ; P<0.001)$ due to an important proportion of legumes of high nutritive quality on these plots.

\section{Discussion}


Species rich subalpine acid grasslands, regardless their management background (grazing or hay making) and the period when they were started (1930's, 1960's or 1980/90's) seem to respond in a similar way to short-term perturbations and manipulation of soil nutrient availability. Other long-term experiments in the Swiss Alps where lime and fertiliser were added from 1932 to 1935 (Lüdi, 1959; Dähler, 1992; Hegg et al., 1992; Spiegelberger et al., 2006) and the Czech Giant Mountains (Hejcman et al., 2007; Klaudisova et al., 2009) where lime and fertiliser were added from 1965 to 1967 showed similar patterns in their resilience compared to the here presented experiment.

In our study above-ground productivity quickly increased by about $40 \%$ during the first 3 years following liming and fertilisation (unpubl. data), probably as a consequence of an increased availability of soil nutrients, but this trend reversed when the treatments were stopped. A similar pattern was found at Schynige Platte (Lüdi, 1959) where biomass production began to decrease in the early 1940s, five years after cessation of the treatments. So consistently, above-ground biomass of mountain grasslands seems to reverse - similarly to experiments in lowlands (Willems and Nieuwstadt, 1996; Hrevusova et al., 2009) - to its original level within about a decade, while other ecosystem properties (e.g. vegetation composition or soil chemical composition, but see below) still remain changed.

The vegetation composition was still remarkably different between limed and unlimed plots. Already after three consecutive years of liming vegetation composition was substantially changed: the proportion of $N$. stricta declined from $20 \%$ to $10 \%$ in the limed plots until 1997, when N. stricta represented only $2 \%$ of the vegetation cover (Brau-Nogue, 1996). Ten years later, i.e. 15 years after cessation of the treatments, acidophilous grasses (N. stricta and D. flexuosa) and forbs and legumes typical of nutrient-poor habitats (A. montana, Campanula 
barbata L., Homogyne alpina Cass., T. alpinum), which initially were dominant, were still less abundant on limed plots than more generalist species and more valuable fodder grasses (F. rubra, P. alpinum, T. pratense) and did not (yet) recover from this disturbance.

Similarly, vegetation composition between fertilised and unfertilised plots was 15 years after cessation of the treatments still different. In contrast to other studies (Willems and Nieuwstadt, 1996), it was not the cover of large grasses, but the cover of legumes which was particularly different between fertilised and unfertilised plots (cf. Table 2). Phosphorus fertilisation has been shown to have long-term effects on plant composition because it is not effectively removed through harvesting (Ekholm et al., 2005) and tends to accumulate in the soil as calcium-phosphate. As a consequence, vegetation composition remains often changed for several years after cessation of fertiliser applications (Marini et al., 2007). However, while vegetation composition is still different, resilience of the species richness and biomass was achieved after 15 years as already shown for other grasslands (Hrevusova et al., 2009).

Despite this shift in vegetation composition in both treatments towards species commonly seen as more productive, aboveground biomass did not reflect this difference. We suggest that an initial fertilisation leads to a higher plant $\mathrm{N}$ concentration, which would make this plant material more easily degradable (Knorr et al., 2005). However, while we detected changes through NIRS-analysis in the leaf quality due to liming, we did not detect such changes neither in the litter, nor in the soil quality. Interestingly, both liming and fertilisation led to a depletion of soil $\mathrm{N}$ concentration, but plant $\mathrm{N}$ concentration was only higher in the fertilised plots and not in limed ones. 
Liming quickly increased the soil $\mathrm{pH}$ and soil nutrient availability after three years and induced a change in the vegetation composition (Brau-Nogue, 1996). With time, it can be expected that soil returns to initially poor and acid conditions. However, our results show that 15 years later soil $\mathrm{pH}$ is still affected by liming, as $\mathrm{pH}$ on plots that received lime was still higher than on control plots. The difference in $\mathrm{pH}$ is relatively small (5.93 vs. 5.25) but represents an about $30 \%$ higher $\mathrm{H}^{+}$-concentration in the unlimed compared to the limed plots.

The long-term effects on vegetation are also visible through the strong increase of the pastoral value. 15 years after the last treatment, pastoral value is about $40 \%$ higher on limed and fertilised plots than on control plots indicating that fodder quality can be improved for a long period of time with low input of lime and fertilizer. However, we did not observe any long term effects of treatments on species richness or diversity. Long-term effects of liming on vegetation composition have been observed in other experiments (Hegg et al., 1992; Hejcman et al., 2007; Klaudisova et al., 2009). They are mainly attributed to direct and indirect effects of lime through increase of the soil $\mathrm{pH}$ and improvement of the nutrient availability. Acidophilous and oligotrophic species are often disadvantaged by a higher $\mathrm{Ca}^{2+}$ as these species are not physiologically adapted to acid soils and do not withstand an increase in $\mathrm{Ca}^{2+}$ concentration and indirectly by competitive exclusion (Grime et al., 2007).

In conclusion, our study shows that even short-term soil amendments in species rich mountain grasslands dominated by nard grass can substantially increase their pastoral values. This increase may persist over periods of time that far exceed the period of influence on biomass, due to changes in vegetation composition or nutrient content. However, from a conservational point of view, these ecosystems, which stand on the priority list of the EU-habitats, may persistently be altered as some typical plant species were replaced on the long-term by much 
more common species. Management methods commonly used to manage such ecosystems as frequent cutting may not be sufficient to allow recovery from disturbances like soil amendments. We highly recommend not only using one (easily measurable) ecosystem component such as above-ground biomass to estimate the resilience of those habitats, but rather assessing the state of the ecosystem return towards its initial composition through vegetation composition and soil chemical properties.

\section{Acknowledgments}

We are grateful to Fréderic Braisaz who allowed André Bornard to install the experiment in 1989. Financial support for field work was provided by Cemagref. Comments by A. Buttler, R. Eschen, K. Lannas, G. Loucougaray, the editor and two anonymous reviewers on a previous version did substantially improve the manuscript.

\section{References}

Bååth, E., Anderson, T.H., 2003. Comparison of soil fungal/bacterial ratios in a pH gradient using physiological and PLFA-based techniques. Soil Biol. Biochem. 35, 955-963.

Brau-Nogue, C., 1996. Dynamique des pelouses d'alpages laitiers des Alpes du Nord externes. Département de Biologie, Joseph Fourier, Grenoble, France.

Cornelissen, J.H.C., Pérez-Harguindeguy, N., Diaz, S., Grime, J.P., Marzano, B., Cabido, M., Vendramini, F., Cerabolini, B., 1999. Leaf structure and defence control litter decomposition rate across species and life forms in regional floras on two continents. New Phytol. 143, 191-200.

Crawley, M.J., Johnston, A.E., Silvertown, J., Dodd, M., Mazancourt, C.d., Heard, M.S., Henman, D.F., Edwards, G.R., 2005. Determinants of species richness in the park grass experiment. Am. Nat. 165, 179-192. 
Daget, P., Poissonet, J., 1972. Un procédé d'estimation de la valeur pastorale des pâturages. Fourrages 49, 31-39.

Dähler, W., 1992. Long term influence of fertilization in a Nardetum. Vegetatio 103, 135-140.

DeAngelis, D.L., Bartell, S.M., Brenkert, A.L., 1989. Effects of nutrient recycling and foodchain length on resilience. Am. Nat. 134, 778-805.

Ekholm, P., Turtola, E., Gronroos, J., Seuri, P., Ylivainio, K., 2005. Phosphorus loss from different farming systems estimated from soil surface phosphorus balance. Agric. Ecosys. Environ. 110, 266-278.

Grime, J.P., Hodgson, J.G., Hunt, R., 2007. Comparative Plant Ecology. Castlepoint Press, Dalbeattie.

Hegg, O., Feller, U., Dähler, W., Scherrer, C., 1992. Long term influence of fertilization in a Nardetum. Vegetatio 103, 151-158.

Hejcman, M., Klaudisova, M., Stursa, J., Pavlu, V., Schellberg, J., Hejcmanova, P., Hakl, J., Rauch, O., Vacek, S., 2007. Revisiting a 37 years abandoned fertilizer experiment on Nardus grassland in the Czech Republic. Agric. Ecosys. Environ. 118, 231-236.

Hrevusova, Z., Hejcman, M., Pavlu, V.V., Hakl, J., Klaudisova, M., Mrkvicka, J., 2009. Long-term dynamics of biomass production, soil chemical properties and plant species composition of alluvial grassland after the cessation of fertilizer application in the Czech Republic. Agric. Ecosys. Environ. 130, 123-130.

Klaudisova, M., Hejcman, M., Pavlu, V., 2009. Long-term residual effect of short-term fertilizer application on $\mathrm{Ca}, \mathrm{N}$ and $\mathrm{P}$ concentrations in grasses Nardus stricta L. and Avenella flexuosa L. Nutr. Cycl. Agroecosys. 85, 187-193.

Knorr, M., Frey, S.D., Curtis, P.S., 2005. Nitrogen additions and litter decomposition: a metaanalysis. Ecology 86, 3252-3257. 
Landolt, E., 1977. Ökologischer Zeigerwert zur Schweizer Flora. Veröffentlichungen des Geobotanischen Instituts ETH, Zürich.

Leps, J., Smilauer, P., 2003. Multivariate Analysis of Ecological Data using CANOCO. Cambridge University Press, Cambridge.

Lüdi, W., 1959. Versuche zur Alpweidenverbesserung auf der Schynigen Platte bei Interlaken. Alpengarten Schynige Platte, Interlaken, pp. 1-8.

Marini, L., Scotton, M., Klimek, S., Isselstein, J., Pecile, A., 2007. Effects of local factors on plant species richness and composition of Alpine meadows. Agric. Ecosys. Environ. 119, 281-288.

May, R.M., 1973. Stability and Complexity in Model Ecosystems. Princeton University Press, Princeton, NJ.

Schellberg, J., Moseler, B.M., Kuhbauch, W., Rademacher, I.F., 1999. Long-term effects of fertilizer on soil nutrient concentration, yield, forage quality and floristic composition of a hay meadow in the Eifel mountains, Germany. Grass Forage Sci. 54, 195-207.

Semelová, V., Hejcman, M., Pavl, V., Vacek, S., Podrázský, V., 2008. The Grass Garden in the Giant Mts. (Czech Republic): Residual effect of long-term fertilization after 62 years. Agric. Ecosys. Environ. 123, 337-342.

Silvertown, J., Poulton, P., Johnston, E., Edwards, G., Heard, M., Biss, P.M., 2006. The Park Grass Experiment 1856-2006: Its contribution to ecology. J. Ecol. 94, 801-814.

Smits, N.A.C., Willems, J.H., Bobbink, R., 2008. Long-term after-effects of fertilisation on the restoration of calcareous grasslands. Appl. Veg. Sci. 11, 279-U292.

Spiegelberger, T., Hegg, O., Matthies, D., Hedlund, K., Schaffner, U., 2006. Long-term effects of short-term perturbation in a sub-alpine grassland. Ecology 87, 1939-1944.

Wardle, D.A., 2002. Communities and Ecosystems - Linking the Aboveground and Belowground Components. Princeton University Press, Princeton, NJ. 
Willems, J.H., Nieuwstadt, M.G.L.v., 1996. Long-term after effects of fertilization on above1 ground phytomass and species diversity in calcareous grassland. J. Veg. Sci. 7, 177-184. 
Table 1: Analysis of variance model of the effects of block, liming (Ca) and fertilisation (PK), and the interaction of liming and fertilisation $(\mathrm{Ca} \times \mathrm{PK})$ on soil $\mathrm{pH}$, soil $\mathrm{N}$ and $\mathrm{C}$-content and soil R and N-Landolt values of a subalpine acid grassland 15 years after abandonment of the treatments. Significant $P$-values $(P<0.05)$ are highlighted.

\begin{tabular}{|c|c|c|c|c|c|c|c|c|c|c|c|}
\hline & \multirow[b]{2}{*}{ Df } & \multicolumn{2}{|c|}{$\mathrm{pH}$} & \multicolumn{2}{|c|}{ N-content } & \multicolumn{2}{|c|}{ C-content } & \multicolumn{2}{|c|}{$\mathrm{N}$-value } & \multicolumn{2}{|c|}{ R-value } \\
\hline & & $F$ & $P$ & $F$ & $P$ & $F$ & $P$ & $F$ & $P$ & $F$ & $P$ \\
\hline Block & 2 & 1.3 & 0.283 & 2.0 & 0.215 & 0.2 & 0.837 & 12.2 & 0.008 & 3.2 & 0.113 \\
\hline $\mathrm{Ca}$ & 1 & 134.4 & $<0.001$ & 10.0 & 0.020 & 4.0 & 0.093 & 38.6 & $<0.001$ & 32.0 & $<0.001$ \\
\hline PK & 1 & 0 & 0.926 & 9.0 & 0.024 & 6.3 & 0.045 & 41.4 & $<0.001$ & 22.5 & 0.003 \\
\hline Ca x PK & 1 & 14.9 & 0.001 & 2.1 & 0.195 & 3.1 & 0.128 & 11.8 & 0.014 & 2.8 & 0.145 \\
\hline Residuals & 30 & & & & & & & & & & \\
\hline
\end{tabular}


Table 2: Mean percent cover $( \pm$ SE) of the most abundant plant species per plot in each treatment and analysis of variance model for liming and fertilisation 15 years after abandonment of the treatments. Significant $P$-values $(P<0.05)$ are highlighted.

\begin{tabular}{|c|c|c|c|c|c|c|c|c|c|c|c|}
\hline & \multirow{2}{*}{$\begin{array}{c}\text { R- } \\
\text { value }\end{array}$} & \multirow{2}{*}{$\begin{array}{c}\mathrm{N}- \\
\text { value }\end{array}$} & \multirow{2}{*}{$\begin{array}{c}\text { Is- } \\
\text { value }\end{array}$} & \multicolumn{4}{|c|}{ Liming } & \multicolumn{4}{|c|}{ Fertilisation } \\
\hline & & & & $\mathrm{Ca}-$ & $\mathrm{Ca}+$ & $F$ & $P$ & PK - & $\mathrm{PK}+$ & $F$ & $P$ \\
\hline Arnica montana & 2 & 2 & 0 & $2.1 \pm 0.77$ & $0.2 \pm 0.13$ & 7.2 & 0.036 & $0.3 \pm 0.18$ & $2.0 \pm 0.77$ & 5.7 & 0.055 \\
\hline Deschampsia flexuosa & 2 & 2 & 1 & $9.8 \pm 1.02$ & $5.4 \pm 0.79$ & 10.9 & 0.016 & $8.2 \pm 0.88$ & $7.0 \pm 1.17$ & 0.9 & 0.388 \\
\hline Festuca rubra & 3 & 3 & 2 & $12.7 \pm 1.26$ & $22.5 \pm 1.90$ & 7.8 & 0.031 & $18.2 \pm 2.42$ & $16.9 \pm 1.46$ & 0.1 & 0.729 \\
\hline Gentiana kochiana & 2 & 2 & 0 & $2.3 \pm 0.27$ & $1.2 \pm 0.25$ & 11.5 & 0.015 & $2.2 \pm 0.27$ & $1.3 \pm 0.28$ & 6.6 & 0.042 \\
\hline Nardus stricta & 2 & 2 & 0 & $12.9 \pm 2.44$ & $2.0 \pm 0.50$ & 21.1 & 0.004 & $9.9 \pm 2.77$ & $4.9 \pm 1.21$ & 3.0 & 0.135 \\
\hline Phleum alpinum & 2 & 2 & 3 & $5.9 \pm 1.27$ & $7.8 \pm 0.94$ & 6.2 & 0.047 & $5.7 \pm 1.26$ & $8.1 \pm 0.91$ & 8.6 & 0.026 \\
\hline Trifolium alpinum & 2 & 2 & 3 & $4.3 \pm 0.74$ & $0.2 \pm 0.10$ & 23.6 & 0.003 & $2.5 \pm 0.77$ & $2.0 \pm 0.66$ & 0.5 & 0.515 \\
\hline Trifolium badium & 4 & 3 & 2 & $0.1 \pm 0.11$ & $4.5 \pm 2.36$ & 13.5 & 0.010 & $0.7 \pm 0.36$ & $3.9 \pm 2.39$ & 2.7 & 0.150 \\
\hline Trifolium pratense & 3 & 3 & 4 & $3.9 \pm 1.45$ & $8.6 \pm 1.65$ & 33.9 & 0.001 & $3.0 \pm 0.93$ & $9.4 \pm 1.84$ & 40.5 & $<0.001$ \\
\hline Trifolium repens & 3 & 4 & 4 & $0.4 \pm 0.20$ & $3.8 \pm 1.82$ & 13.5 & 0.010 & $0.7 \pm 0.34$ & $3.5 \pm 1.82$ & 6.5 & 0.044 \\
\hline
\end{tabular}


Table 3: Analysis of variance model of the effects of block, liming (Ca) and fertilisation (PK), and the interaction of liming and fertilisation $(\mathrm{Ca} \times \mathrm{PK})$ on plant tissue $\mathrm{N}$ - and $\mathrm{C}$-content of a subalpine acid grassland 15 years after abandonment of the treatments. Significant $P$-values $(P<0.05)$ are highlighted.

\begin{tabular}{|c|c|c|c|c|c|c|c|}
\hline & \multirow[b]{2}{*}{ Df } & \multicolumn{2}{|c|}{$\mathrm{N}$-content } & \multicolumn{2}{|c|}{ C-content } & \multicolumn{2}{|c|}{$\mathrm{C} / \mathrm{N}$} \\
\hline & & $F$ & $P$ & $F$ & $P$ & $F$ & $P$ \\
\hline Block & 2 & 6.2 & 0.035 & 0.7 & 0.526 & 4.7 & 0.058 \\
\hline $\mathrm{Ca}$ & 1 & 0.8 & 0.398 & 19.1 & 0.005 & 4.9 & 0.068 \\
\hline $\mathrm{PK}$ & 1 & 32.1 & 0.001 & 5.4 & 0.059 & 27.4 & 0.002 \\
\hline $\mathrm{Ca} \times \mathrm{PK}$ & 1 & 0.6 & 0.610 & 0.05 & 0.835 & 0.006 & 0.941 \\
\hline Residuals & 30 & & & & & & \\
\hline
\end{tabular}




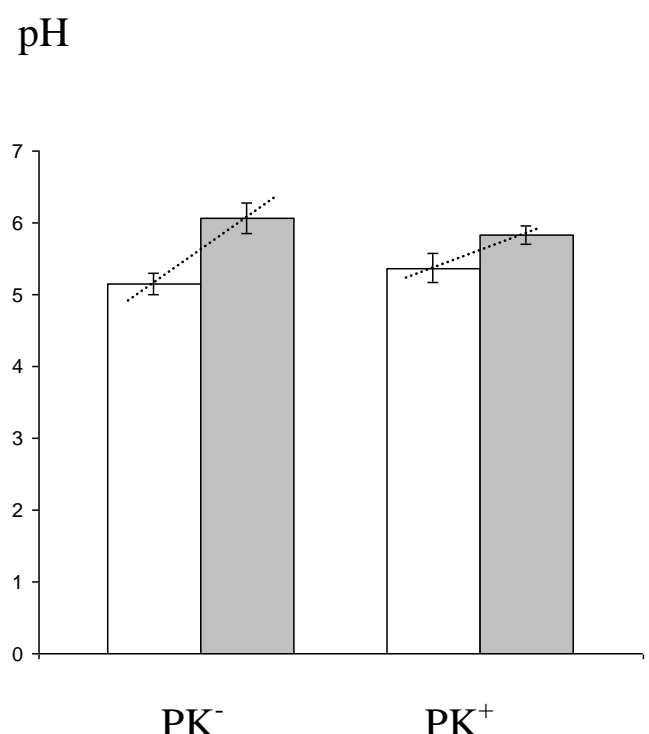

Fig. 1: Mean soil $\mathrm{pH}$ and $\mathrm{SE}$ of a subalpine acid grassland 15 years after abandonment of liming and fertilisation (PK). White colons: no liming $\left(\mathrm{Ca}^{-}\right)$; gray colons: liming $\left(\mathrm{Ca}^{+}\right)$. Dotted lines were added to visualise the stronger increase in $\mathrm{pH}$ when plots were not fertilised. For statistics see Table 1. 
Annex 1: Relative cover of plant species assessed by point intercept method of a subalpine acid grassland in 1989 before the start of the fertilisation and liming treatments (data taken from Brau-Nogue, 1996).

\begin{tabular}{|c|c|c|c|c|c|c|c|c|c|c|c|c|c|}
\hline & Plot 1 & Plot 2 & Plot 3 & Plot 4 & Plot 5 & Plot 6 & Plot 7 & Plot 8 & Plot 9 & Plot 10 & Plot 11 & Plot 12 & Mean \\
\hline Deschampsia flexuosa & 23.5 & 17.3 & 21.5 & 24.8 & 15.7 & 23.3 & 20.8 & 18.4 & 17.6 & 15.8 & 24.7 & 17.9 & 20.1 \\
\hline Nardus stricta & 14.1 & 18.5 & 15.1 & 16.8 & 22.5 & 14.0 & 12.5 & 11.5 & 25.0 & 21.1 & 19.8 & 17.9 & 17.4 \\
\hline Potentilla erecta & 5.9 & 9.9 & 7.5 & 5.0 & 6.7 & 7.0 & 5.6 & 13.8 & 11.8 & 11.8 & 11.1 & 5.1 & 8.4 \\
\hline Leontodon sp. & 9.4 & 14.8 & 12.9 & 13.9 & 12.4 & 8.1 & 2.8 & 6.9 & 0.0 & 2.6 & 2.5 & 2.6 & 7.4 \\
\hline Geum montanum & 5.9 & 8.6 & 10.8 & 5.0 & 15.7 & 5.8 & 6.9 & 5.7 & 10.3 & 5.3 & 2.5 & 2.6 & 7.1 \\
\hline Gentiana kochiana & 1.2 & 7.4 & 1.1 & 2.0 & 7.9 & 4.7 & 4.2 & 3.4 & 5.9 & 3.9 & 8.6 & 6.4 & 4.7 \\
\hline Festuca rubra & 7.1 & 3.7 & 4.3 & 5.0 & 2.2 & 1.2 & 9.7 & 6.9 & 1.5 & 1.3 & 1.2 & 6.4 & 4.2 \\
\hline Trifolium alpinum & 7.1 & 6.2 & 2.2 & 5.9 & 1.1 & 3.5 & 2.8 & 3.4 & 2.9 & 1.3 & 3.7 & 7.7 & 4.0 \\
\hline Meum athamanticum & 3.5 & 0.0 & 2.2 & 3.0 & 1.1 & 2.3 & 8.3 & 6.9 & 4.4 & 5.3 & 2.5 & 3.8 & 3.6 \\
\hline Campanula barbata & 2.4 & 2.5 & 4.3 & 3.0 & 1.1 & 2.3 & 1.4 & 5.7 & 2.9 & 1.3 & 3.7 & 1.3 & 2.7 \\
\hline Euphorbia sp. & 0.0 & 0.0 & 0.0 & 0.0 & 0.0 & 0.0 & 0.0 & 1.1 & 5.9 & 10.5 & 4.9 & 9.0 & 2.6 \\
\hline Plantago alpina & 0.0 & 2.5 & 3.2 & 3.0 & 2.2 & 4.7 & 1.4 & 3.4 & 5.9 & 1.3 & 1.2 & 1.3 & 2.5 \\
\hline Phleum alpinum & 0.0 & 0.0 & 1.1 & 0.0 & 4.5 & 7.0 & 2.8 & 1.1 & 0.0 & 1.3 & 2.5 & 5.1 & 2.1 \\
\hline Potentilla aurea & 2.4 & 1.2 & 2.2 & 4.0 & 2.2 & 5.8 & 1.4 & 1.1 & 1.5 & 0.0 & 0.0 & 1.3 & 1.9 \\
\hline Luzula sp. & 0.0 & 0.0 & 2.2 & 1.0 & 2.2 & 1.2 & 0.0 & 1.1 & 0.0 & 1.3 & 2.5 & 1.3 & 1.1 \\
\hline Vaccinium myrtillus & 1.2 & 0.0 & 3.2 & 1.0 & 0.0 & 3.5 & 0.0 & 0.0 & 0.0 & 0.0 & 1.2 & 2.6 & 1.1 \\
\hline Arnica montana & 2.4 & 2.5 & 0.0 & 1.0 & 0.0 & 0.0 & 1.4 & 1.1 & 0.0 & 0.0 & 0.0 & 0.0 & 0.7 \\
\hline
\end{tabular}




\begin{tabular}{|c|c|c|c|c|c|c|c|c|c|c|c|c|c|}
\hline Phyteuma sp. & 3.5 & 1.2 & 1.1 & 1.0 & 0.0 & 0.0 & 0.0 & 0.0 & 0.0 & 0.0 & 1.2 & 0.0 & 0.7 \\
\hline Hypericum sp. & 0.0 & 0.0 & 0.0 & 1.0 & 0.0 & 0.0 & 4.2 & 1.1 & 0.0 & 0.0 & 0.0 & 1.3 & 0.6 \\
\hline Anthoxanthum odoratum & 0.0 & 0.0 & 1.1 & 0.0 & 0.0 & 0.0 & 1.4 & 2.3 & 0.0 & 1.3 & 0.0 & 0.0 & 0.5 \\
\hline Homogyne alpina & 0.0 & 0.0 & 0.0 & 0.0 & 0.0 & 1.2 & 1.4 & 0.0 & 0.0 & 1.3 & 0.0 & 0.0 & 0.3 \\
\hline Hieracium $s p$. & 0.0 & 1.2 & 0.0 & 0.0 & 0.0 & 0.0 & 1.4 & 0.0 & 0.0 & 0.0 & 0.0 & 0.0 & 0.2 \\
\hline Silene vulgaris & 0.0 & 0.0 & 0.0 & 0.0 & 0.0 & 0.0 & 1.4 & 0.0 & 0.0 & 0.0 & 1.2 & 0.0 & 0.2 \\
\hline Trifolium pratense & 2.4 & 0.0 & 0.0 & 0.0 & 0.0 & 0.0 & 0.0 & 0.0 & 0.0 & 0.0 & 0.0 & 0.0 & 0.2 \\
\hline Viola sp. & 2.4 & 0.0 & 0.0 & 0.0 & 0.0 & 0.0 & 0.0 & 0.0 & 0.0 & 0.0 & 0.0 & 0.0 & 0.2 \\
\hline Avenula versicolor & 0.0 & 1.2 & 0.0 & 1.0 & 0.0 & 0.0 & 0.0 & 0.0 & 0.0 & 0.0 & 0.0 & 0.0 & 0.2 \\
\hline Carex sempervirens & 0.0 & 0.0 & 0.0 & 0.0 & 0.0 & 0.0 & 1.4 & 0.0 & 0.0 & 0.0 & 0.0 & 0.0 & 0.1 \\
\hline Polygala sp. & 0.0 & 0.0 & 0.0 & 0.0 & 0.0 & 0.0 & 1.4 & 0.0 & 0.0 & 0.0 & 0.0 & 0.0 & 0.1 \\
\hline Ranunculus sp. & 0.0 & 0.0 & 0.0 & 0.0 & 0.0 & 0.0 & 0.0 & 0.0 & 0.0 & 0.0 & 0.0 & 1.3 & 0.1 \\
\hline Agrostis vulgaris & 0.0 & 0.0 & 0.0 & 0.0 & 0.0 & 0.0 & 0.0 & 0.0 & 0.0 & 0.0 & 1.2 & 0.0 & 0.1 \\
\hline Ranunculus acris & 0.0 & 0.0 & 0.0 & 0.0 & 0.0 & 0.0 & 0.0 & 0.0 & 0.0 & 0.0 & 1.2 & 0.0 & 0.1 \\
\hline Poa alpina & 1.2 & 0.0 & 0.0 & 0.0 & 0.0 & 0.0 & 0.0 & 0.0 & 0.0 & 0.0 & 0.0 & 0.0 & 0.1 \\
\hline Cerastium sp. & 0.0 & 0.0 & 0.0 & 0.0 & 0.0 & 0.0 & 0.0 & 1.1 & 0.0 & 0.0 & 0.0 & 0.0 & 0.1 \\
\hline Crocus vernus & 0.0 & 0.0 & 1.1 & 0.0 & 0.0 & 0.0 & 0.0 & 0.0 & 0.0 & 0.0 & 0.0 & 0.0 & 0.1 \\
\hline Ranunculus breyninus & 0.0 & 0.0 & 0.0 & 1.0 & 0.0 & 0.0 & 0.0 & 0.0 & 0.0 & 0.0 & 0.0 & 0.0 & 0.1 \\
\hline
\end{tabular}

